\title{
4th World Conference on Ecological Restoration
}

\author{
Steve Whisenant
}

A remarkable gathering of restoration practitioners, regulators, scientists, educators, and supporters took place in Merida, Mexico last August 21-25. I was fortunate to be among the 1,000 participants from 60 countries. The 3-day scientific program was organized around the social, economic, and functional aspects of restoration - with an entire day devoted to each of those three themes. We also had nearly 300 poster presentations on a wide range of restoration topics. I was especially pleased by the growing participation of students and young professionals in SER conferences.

At each of our conferences, SER recognizes a few of the most deserving individuals or organizations that have made outstanding contributions to ecological restoration. During the meeting in Merida, SER recognized three very deserving individuals:

1. The Theodore M. Sperry Award was presented to Dr. Steven N. Handel of Rutgers, The State University of New Jersey and the Center for Urban Restoration Ecology. Dr. Handel is also the current Editor of Ecological Restoration. This award is presented to "individuals that have made significant advancements to the science and/ or practice of ecological restoration." As a pioneer in the restoration of degraded urban sites, Dr. Handel's accomplishments are important and continue to have far-reaching impacts.

2. The John Rieger Award was presented to Dr. Peter C. 'Rocky' Smiley, Jr. of the USDA Agricultural Research Station in Columbus, Ohio. The John Rieger Awardnamed in honor of SER's first President-recognizes those who have dedicated their time and skills to the advancement of ecological restoration and/or to the development of the Society. Dr. Smiley's tireless enthusiasm is well known to those in the Midwest-Great Lakes Chapter. His enthusiasm and organizational efforts helped reinvigorate that chapter.

3. The Communications Award was presented to Jesus Matos Mederos for his promotion of ecological restoration in Cuba and Latin America. This award

Ecological Restoration Vol. 30, No. 1, 2012

ISSN 1522-4740 E-ISSN 1543-4079

(C2012 by the Board of Regents of the University of Wisconsin System. acknowledges individuals or groups that increase public awareness and acceptance of ecological restoration. As the founder of RIACRE (Red Iberoamericana y del Caribe de Restauracion Ecologica), Mr. Matos Mederos has organized several international meetings, including the 2007 and 2009 Simposios Internationales sobre Restauracion Ecologica in Santa Clara, Cuba. His numerous activities were instrumental in communicating the benefits and successes of ecological restoration throughout Latin America.

SER presented a Special Recognition Award to the "Contracting Parties to the United Nations Convention on Biological Diversity (CBD)." This award, accepted by Kalemani Jo Mulongoy, recognizes the CBD's efforts to promote both the conservation of biodiversity and the necessity of using ecological restoration to assist with conservation. The CBD's new strategic plan provides a framework for national governments to combat biodiversity loss through, among other things, ensuring that the benefits of ecosystem services to all populations will be enhanced through an ecological restoration program, with an emphasis on those areas that provide crucial ecosystem services to people.

George D. Gann was honored with a Chair Emeritus title in recognition of his extraordinary service to the Society. Mr. Gann is the Executive Director of The Institute for Regional Conservation in Miami, Florida. He served on the SER Board of Directors for 17 years, including twice as Chair. The only other time SER similarly honored a past leader was in 2005, when Andre Clewell was awarded the President Emeritus title.

Marik Wilkerson a student of the University of California, Davis received the William Niering Student Presentation Award. This award is given to the student that makes the most outstanding oral presentation during a SER World Conference.

World Conferences on Ecological Restoration enlighten attendees, whatever the background, goals or interests. So mark your calendars - the SER2013 World Conference on ecological restoration will be held in Madison, Wisconsin October 6-11, 2013. Madison would be an exciting location anytime, but 2013 is especially appropriate. The Society for Ecological Restoration was founded 
at the University of Wisconsin-Madison Arboretum in 1988. So plan to attend the $5^{\text {th }}$ World Conference on Ecological Restoration on the $25^{\text {th }}$ anniversary of the Society for Ecological Restoration. I look forward to seeing you there. Fortunately, you need not wait two years to attend an ecological restoration conference. SER Chapters in the U.S. hold excellent annual conferences and provide regional opportunity to meet new colleagues and renew old friendships. You can find information on those conferences by going to the www.ser.org website, selecting "Regional Chapters" and then linking to the chapter in your region. I also recommend the $8^{\text {th }}$ European Conference on Ecological Restoration, to be held in Ceske Budejovice, Czech Republic, 9-12 September, 2012 (www.ecer2012.eu/).

Steve Whisenant

Chair

Society for Ecological Restoration

\section{ECOLOGICAL RESTORATION 29(3) ERRATA}

1. In the Restoration Note entitled "Tipped Over Duck Nest Box Traps Turtles in a Restored Wetland (Ohio)" (pp. 211-212) the image in Figure 2 should be paired with the Figure 1 (above) caption. The image in Figure 1 (above) should be paired with the Figure 2 caption.
2. In the article entitled, "Converting Riparian Restoration Waste to Energy: Testing Tamarisk (Tamariz spp.) Woody Biomass as Fuel for Downdraft Gasification," the 2nd paragraph, 4th sentence on p. 271 should read, "In June 2010, in response to concerns that the biological control of tamarisk could negatively impact the endangered southwestern willow flycatcher (Empodinax trailii extimus), which has been observe nesting in tamarisk, sometimes preferentially, the USDA issued a moratorium ..." 